To cite this article: Coca-Stefaniak, J.A. (2019), "Marketing smart tourism cities - a strategic dilemma", International Journal of Tourism Cities, Vol. 5, No. 4.

\title{
Marketing smart tourism cities - a strategic dilemma
}

\author{
J. Andres Coca-Stefaniak ${ }^{\text {a * }}$
}

${ }^{\text {a }}$ University of Greenwich, Business School, Department of Marketing, Events and

Tourism, Old Royal Naval College, Park Row, London SE10 9LS, United Kingdom. Tel. +44 (0)2083318309.

\section{Introduction: Are smart tourism cities counterproductive to memorable visitor experiences?}

There is a growing consensus among scholars in neuroscience with regards to the adverse effects of technology on the cognitive functions of the human brain (Loh and Kanai, 2016). These include the processing of emotions, memory and the storage of lived experiences. In fact, this has been shown to be particularly applicable to regular users of smartphone-based mobile applications (Wilmer et al., 2017). Rather worryingly for today's prevalently technology-based conception of what a smart tourism destination should deliver, recent research has shown that visitors' intentions to preserve the memories of a visit to a tourism attraction by engaging with mobile media (e.g. taking photos and sharing them with others via social media) during their visit may actually prevent those same visitors (though perhaps not the recipients of their photos via social media) from remembering the very experience they are trying to preserve (Tamir et al., 2018; see also Soares and Storm, 2018). Furthermore, research

* Corresponding author. Email address: a.coca-stefaniak@gre.ac.uk (J.A. Coca-Stefaniak). 
has also shown that this 'hyperconnected' state of affairs may be altogether detrimental to visitors' enjoyment of the overall experience (Barasch et al., 2017). For those tourists who can still boast an adequate level of battery charge on their smartphones after a busy visit spent updating social media profiles with new photos whilst trying to simultaneously absorb the multi-sensory experience offered by the tourist attraction, there is further bad news. Similar neurological research has shown that people who are over-reliant on satellite navigation systems for way-finding (say, back to the hotel or to a restaurant highly rated on Tripadvisor) tend to perform worse at finding their way in the absence of their digital aid than those who rely on paper maps (McCullough and Collins, 2019). Parallel research in tourism has argued that this 'smart' technology-enabled tourist may run the risk of alienation (or "e-lienation", to use the term coined by Tribe and Mkono, 2017) from their surroundings and missing out on potentially enriching experiences offered by the tourism destination. All in all, this should be rather worrying news for aspiring and existing smart tourism destinations. Why? Well, given that memorable experiences remain arguably a desirable goal in the design and delivery of visitor experiences, it appears that technology could be actually conspiring to rewire our brains in the opposite direction (Ward, 2013). Should, then, smart tourist destinations strive to become more efficient at delivering other services instead of memorable experiences? Maybe, though this is perhaps particularly applicable to some of the earlier models in the smart cities longitudinal spectrum. In fact, there is growing consensus around the fact that technological innovation (Pinke-Sziva et al., 2019; Skeli and Schmid, 2019) can alleviate some of the effects of overtourism, particularly in the context of smart tourism destinations (Gretzel and ScarpinoJohns, 2018). This includes 'smarter' transport solutions, even if we know that residents and tourists will differ considerably in their assessment of urban mobility improvements (Albalate and Bel, 2010). However, all this is part of what smart cities (presumably) do already. Consequently, if the whole raison d'être of the 'smart' concept applied to tourism destinations rests mainly on the proviso of experience design and delivery, where do the insights from the latest neurological research leave smart tourism destinations? Should the next generation of smart tourism destinations re-consider their strategic focus altogether?

This special issue of the International Journal of Tourism Cities (IJTC) on "Overtourism and the Marketing of Smart Tourism Destinations" attempts to shed light not only on the overtourism phenomena but also on a nascent field of research: the marketing and branding of smart urban tourism destinations. Inevitably, and given that both topics can hardly be considered in isolation, much of the research showcased in this special issue, including this 
editorial, explore also elements spanning the overtourism phenomena and the marketing and management of smart tourism destinations, chiefly from an urban perspective.

\section{Are overtourism and smartness linked in the development of global tourism cities?}

As things stand, there is probably insufficient empirical evidence yet to deliver a categorical answer to what would appear to be a relatively intuitive question. Incidentally, many of the global tourism cities displaying symptoms of overtourism (e.g. Berlin, Barcelona, Venice, Amsterdam, Prague, Rome, etc.) are also cities with proven smart tourism credentials. However, as Dodds and Butler point out in their literature review of longitudinal issues in tourism development ("The phenomena of overtourism: a review"), overtourism remains a complex issue often focused on very specific locations within global tourism cities. Some of these major mobility nodes and/or bottlenecks (e.g. canals, key bridges, major avenues) often bring to the forefront the conflicting mobility needs of residents versus tourists. In this respect, Bouchon and Rauscher ("Cities and tourism, a love and hate story; towards a conceptual framework for urban overtourism management") argue succinctly that issues such as urban morphology and the branding strategies of urban tourism destinations can have a major impact on overtourism sentiment. However, they also offer a conceptual framework for the management of overtourism, which hints at a more pro-active role for smart tourism destinations in this arena and advocates implicitly the need to future-proof tourism destinations against overtourism. In an analysis of insights provided by European destination managers, Eckert et al. suggest this could be achieved through more effective leadership provided by destination management organisations ("Strategies and measures directed towards overtourism: a perspective of European DMOs"). However, this leadership needs to be grounded in a clear competence framework for the management of destinations, as Jamieson and Jamieson point out adopting a heritage management perspective on the development of urban tourism destinations ("Overtourism management competencies in Asian urban heritage areas"). Of course, competencies and leadership would be of limited use to effective decisionmaking without the availability of real-time data and trends, which are crucial to processes related to the planning, development and integrated management of tourism destinations. Although tracking technologies and the analysis (and prediction) of tourist footfall have been well documented in the tourism literature (Shoval and Ahas, 2016), often from a capacity management perspective, much of this work has been carried out at a very localised level (e.g. 
festivals, cities, theme parks). Given trends towards a more networked (and regional) approach to the management of smart tourism destinations beyond urban hubs and incorporating smaller towns and attractions nearby (Coca-Stefaniak and Seisdedos, forthcoming) and growing consensus with regards to the fact that tourism should be treated as an open system (Morrison et al., 2018), this is likely to remain a major area of research as well as an opportunity for smart tourism destinations to engage in big data analysis that can then inform increasingly sophisticated destination marketing initiatives.

In spite of the undeniable importance of effective leadership, competencies and reliable data when devising local solutions to issues arising from largely global trends, creativity and creative thinking remain aspects seldom explored in the context of innovation for smart tourism destinations. Trinchini et al. ("Creativity, innovation and smartness in destination branding") explore this conceptually by discussing the role of creativity as a crucial driver of innovation in the design of people-centred smart tourism destination branding strategies. Yet, in spite of the often much lauded new generation of people-centred (otherwise known, perhaps rather clumsily, as "human-centred") smart cities and smart tourism destinations, the role of children in this process has been rather neglected by scholars and largely under-researched. Seraphin and Green attempt to redress this balance with their study of "The significance of the contribution of children to conceptualising the destination of the future", where they explore children's vision(s) of the destination of the future using Winchester (United Kingdom) as a case study. Crucially, and certainly in line with the earlier argument for the need of more creativity in the design of smart tourism destination branding strategies, the authors find that an ambidextrous management approach balancing metaphorical thinking and objective thinking in product and service design may be key to addressing the needs and wants of future generations of customers and visitors. This duality becomes similarly apparent in the survey data analysis of hotel guests presented by Ballina et al. ("The phygital experience in the smart tourism destination") in the context of the use of information and communication technologies in the design of interactive visitor experiences beyond the mainly information-focused services offered by many of today's smart tourism destinations.

Inevitably, issues of co-management and co-design are also at the forefront of research in smart city management and the development of new initiatives in smart tourism destinations. Event if these issues permeate implicitly the arguments of many of the articles published in this special issue, they are particularly well illustrated in the case study presented by Fabry and 
Blanchet ("Monaco's struggle to become a smart destination"), which explores the relationship between the smart city and the smart tourism destination and concludes that the support of local residents for smart innovation initiatives is key to their success. Similarly, Plichta ("Comanagement and stakeholder theory as a useful approach to manage the problem of overtourism in historical cities-illustrated with an example of Krakow") reaches analogous conclusions with regards to the significance of cooperative processes in the design and implementation of initiatives aimed at alleviating overtourism.

Although brand-customer interaction is an established field of knowledge in marketing and consumer behaviour, it remains largely under-researched in the context of smart cities and smart tourism destinations (Molinillo et al., 2019). This theme is picked up by Gretzel and Collier de Mendonça ("Smart destination brands: Semiotic analysis of visual and textual signs") in their semiotic analysis of how two smart tourism sites (destinosinteligentes.es and smarttourismcapital.eu) conceptualise "smartness" to communicate their brand meaningfully to a wide array of stakeholders, even if the approach of these two sites remains somewhat techtopian. In a similar vein though focusing specifically on visitors, Chan et al. 's quantitative study ("Investigating visitors' perception of smart city dimensions for city branding in Hong Kong") reveals that visitors' two key determinants of a successful smart city brand are the quality of smart resident communities and energy management. It remains to be established, however, to what extent tourists from other parts of the world less represented in this study (e.g. Europe, North America, Australasia) would concur.

\section{Future-proofing smart tourism cities - could overtourism be the first test of many others ahead?}

As smart cities continue to evolve towards a more people-centred paradigm increasingly focused on environmental sustainability (Yigitcanlar et al., 2019), their younger sibling concept of smart tourism cities/destinations appears to find itself strategically at a crossroads. One option would be to pursue the path of continuity by remaining in the shadow of smart cities (Jasrotia and Gangotia, 2018) and merely replicating their strategic positioning (VargasSanchez et al., 2019). However, another strategic option for smart tourism cities is to position themselves differently and adopting an alternative paradigm. This could involve a re-think of their strategic positioning towards a more regional networked approach (Coca-Stefaniak and 
Seisdedos, forthcoming), which would help alleviate certain overtourism elements, or even a differentiation-based strategic realignment anchored in their idiosyncrasy or DNA (CocaStefaniak, 2013), which could help global tourism cities to deal with some of the globally homogenising factors affecting the progressive dwindling of the 'authenticity' of their experiences (Knudsen and Waade, 2010; Alvarez, 2010; Martinez, 2016).

Regardless of what strategic positioning is adopted by the next generation of smart tourism cities, there is a growing consensus among scholars and practitioners that one of the defining characteristics of smart tourism destinations should be their ecosystem-centred approach (Gretzel et al., 2015; Boes et al., 2016) to the development and management of tourism as well as its wider challenges, including overtourism. This is also a common thread linking the articles included in this special issue of the International Journal of Tourism Cities. Similarly, the overtourism phenomena echoes earlier research on the limits of acceptable change, used initially for the conservation of wilderness areas (Stankey et al., 1985) and applied later to tourism destinations (Ahn et al., 2002; Frauman and Banks, 2011). Innovation, as shown in many of the articles published in this special issue, also has a pivotal role in the context of smart tourism destinations. However, for smart innovation to succeed in the next generation of smart tourism cities, it will need to evolve from its rather peripheral role at present. In fact, it will need to become integral to the tourism city ecosystem by interacting actively with all its components, as shown conceptually in Figure 1.

(Insert Figure 1 about here)

This new conception of smart innovation, which may include in some instances elements of social innovation, will act as an enabler for destination management organisations in smart tourism cities to expand their remit and influence beyond managing and marketing 'assets' and resources. Smart innovation initiatives will help tourism cities to build resilience to many of the short and medium-term sustainable development challenges illustrated by the limits of 
acceptable change domain, whilst future proofing tourism cities and their surrounding regions adopting an integrated network approach to longer-term issues, including climate change, among others.

As our understanding of the overtourism phenomena continues to develop and the often-uneasy relationship between local stakeholders and urban innovation initiatives such as smart cities and smart tourism destinations matures further (Kaika, 2017), we may still rediscover in the context of marketing and managing tourism cities what our ancestors already knew several centuries (or even millennia) ago. The hapless English poet Francis Thompson (1859-1907) captured this elegantly in a set of verses often adopted today to illustrate concepts such as chaos theory:

\author{
"All things by immortal power, \\ Near or far, \\ Hiddenly \\ To each other linked are, \\ that thou canst not stir a flower \\ without troubling of a star."
}

- Francis Thompson (in: “The Mistress of Vision”)

\title{
References
}

Ahn, B., Lee, B. and Shafer, C.S. (2002), "Operationalizing sustainability in regional tourism planning: an application of the limits of acceptable change framework", Tourism Management, 23(1), pp.1-15.

Albalate, D. and Bel, G. (2010), "Tourism and urban public transport: Holding demand pressure under supply constraints", Tourism Management, 31(3), pp. 425-433. 
Alvarez, M.D. (2010), "Creative cities and cultural spaces: new perspectives for city tourism", International Journal of Culture, Tourism and Hospitality Research, 4(3), pp. 171175.

Barasch, A., Zauberman, G. and Diehl, K. (2017), "How the intention to share can undermine enjoyment: Photo-taking goals and evaluation of experiences", Journal of Consumer Research, 44(6), pp. 1220-1237.

Boes, K., Buhalis, D. and Inversini, A. (2016), "Smart tourism destinations: ecosystems for tourism destination competitiveness", International Journal of Tourism Cities, 2(2), pp. 108124.

Coca-Stefaniak, J.A. and Seisdedos, G. (forthcoming), "Smart urban tourism destinations at a crossroads - when being 'smart' and urban is no longer enough", in: A.M. Morrison and J.A. Coca-Stefaniak (eds.), Routledge Handbook of Tourism Cities, London: Routledge.

Coca-Stefaniak, J.A. (2013), Successful town centres: Developing effective strategies, London: Gloucester First Local Enterprise Partnership

Frauman, E. and Banks, S. (2011), "Gateway community resident perceptions of tourism development: Incorporating importance-performance analysis into a limits of acceptable change framework", Tourism Management, 32(1), pp.128-140.

Gretzel, U., Werthner, H., Koo, C. and Lamsfus, C. (2015), “Conceptual foundations for understanding smart tourism ecosystems", Computers in Human Behavior, 50, pp. 558-563.

Gretzel, U. and Scarpino-Johns, M. (2018), "Destination resilience and smart tourism destinations", Tourism Review International, 22(3-4), pp. 263-276.

Jasrotia, A. and Gangotia, A. (2018), "Smart cities to smart tourism destinations: A review paper", Journal of Tourism Intelligence and Smartness, 1(1), pp.47-56. 
Kaika, M. (2017), “'Don’t call me resilient again!': the New Urban Agenda as immunology ... or... what happens when communities refuse to be vaccinated with 'smart cities' and indicators", Environment and Urbanization, 29(1), pp. 89-102.

Knudsen, B.T. and Waade, A.M. (eds.) (2010), Re-investing authenticity: tourism, place and emotions, Channel View Publ.

Loh, K.K. and Kanai, R. (2016), "How has the Internet reshaped human cognition?", The Neuroscientist, 22(5), pp. 506-520.

Martínez, P.G. (2016), “Authenticity as a challenge in the transformation of Beijing's urban heritage: The commercial gentrification of the Guozijian historic area", Cities, 59, pp.48-56.

McCullough, D. and Collins, R. (2019), “'Are we losing our way?' Navigational aids, sociosensory way-finding and the spatial awareness of young adults", Area, 51(3), pp. 479-488.

Molinillo, S., Anaya-Sánchez, R., Morrison, A.M. and Coca-Stefaniak, J.A. (2019), “Smart city communication via social media: Analysing residents' and visitors' engagement", Cities, 94 , pp. 247-255.

Morrison, A.M., Lehto, X.Y., and Day, J.G. (2018), The Tourism System ( $8^{\text {th }}$ ed.), Dubuque, Iowa: Kendall Hunt Publishing Company.

Pinke-Sziva, I., Smith, M., Olt, G. and Berezvai, Z. (2019), “Overtourism and the night-time economy: a case study of Budapest", International Journal of Tourism Cities, 5(1), pp. 1-16.

Shoval, N. and Ahas, R. (2016), "The use of tracking technologies in tourism research: the first decade", Tourism Geographies, 18(5), pp. 587-606.

Skeli, S. and Schmid, M. (2019), "Mitigating overtourism with the help of smart technology solutions-a situation analysis of European city destinations”, In: ISCONTOUR 2019 Tourism Research Perspectives: Proceedings of the International Student Conference in Tourism Research (Vol. 7, p. 13). 
Soares, J.S. and Storm, B.C. (2018), "Forget in a flash: A further investigation of the phototaking-impairment effect", Journal of Applied Research in Memory and Cognition, 7(1), pp. 154-160.

Stankey, G.H., Cole, D.N., Lucas, R.C., Petersen, M.E. and Frissell, S.S. (1985), The limits of acceptable change (LAC): System for wilderness planning, USDA Forest Service General Technical Paper INT-176.

Tamir, D.I., Templeton, E.M., Ward, A.F. and Zaki, J. (2018), "Media usage diminishes memory for experiences", Journal of Experimental Social Psychology, 76, pp. 161-168.

Tribe, J. and Mkono, M. (2017), "Not such smart tourism? The concept of e-lienation", Annals of Tourism Research, 66, pp. 105-115.

Vargas-Sanchez, A., Abbate, T. and Perano, M. (2019), "Smart destinations: towards a more sustainable tourism industry", In: Management and Sustainability: Creating Shared Value in the Digital Era, Sinergie-SIMA Conference, Sapienza University, Rome, 20-21 June, pp. 95112.

Ward, A.F. (2013), "Supernormal: How the Internet is changing our memories and our minds", Psychological Inquiry, 24(4), pp. 341-348.

Wilmer, H.H., Sherman, L.E. and Chein, J.M. (2017), "Smartphones and cognition: A review of research exploring the links between mobile technology habits and cognitive functioning", Frontiers in Psychology, 8, pp. 605-605.

Yigitcanlar, T., Kamruzzaman, M., Foth, M., Sabatini-Marques, J., da Costa, E. and Ioppolo, G. (2019), "Can cities become smart without being sustainable? A systematic review of the literature", Sustainable Cities and Society, 45, pp. 348-365. 


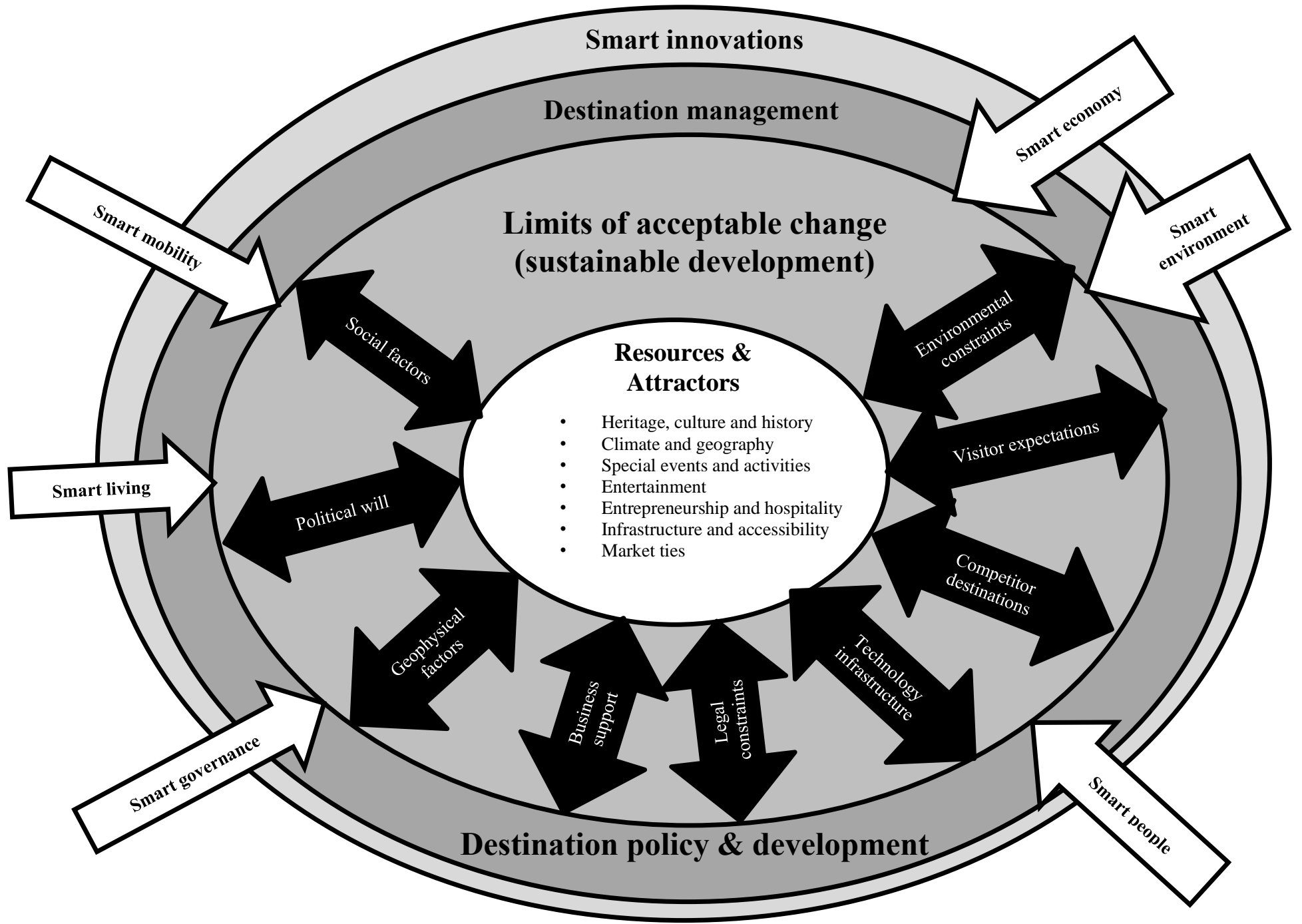

Figure 1. The resilient smart tourism destination - a conceptual framework for future proofing today's smart tourism cities. 